Author approved accepted version of:

Harland C.M., (2021) Discontinuous wefts: weaving a more interconnected Supply Chain Management tapestry, Journal of Supply Chain Management, 57, 1, 27-41 doi:

10.1111/jscm.12249 


\title{
DISCONTINUOUS WEFTS: WEAVING A MORE INTERCONNECTED SUPPLY CHAIN MANAGEMENT TAPESTRY
}

\begin{abstract}
The COVID-19 crisis quickly drew attention to shortages of critical supplies in complex, global healthcare and food supply chains, despite emergency and pandemic plans existing in many countries. Borders and factories closed through lockdowns and slowly reopened under different working arrangements, causing supply chains to struggle to respond to this global crisis, with severe impact on GDPs internationally. Ironically, despite global communications technologies, global political structures and the immense capability of humans, the only true global actor in this crisis is a virus, one of the simplest, most dependent forms of life.
\end{abstract}

Supply chain management research and practice contains threads of knowledge and understanding that are vital to mitigation, preparedness, response and recovery in global crises; we just haven't woven them together yet. This essay proposes a more interconnected approach to supply chain management to tackle this current and future global crises, weaving together understanding of supply markets, public procurement, humanitarian aid supply chain management, network and systems thinking, and global stewardship, with the more traditional conceptualisations of firm-based supply chain management. Questions are posed to illustrate current discontinuous wefts of knowledge to explore how weaving a more interconnected, systems thinking-based approach to supply chain management might stimulate research to support coordination of future global supply preparedness.

\section{Keywords}

Supply markets, public procurement, humanitarian aid supply chain management, networks, systems thinking, global stewardship 


\section{Introduction}

The COVID-19 pandemic shone a spotlight on healthcare and food supply chains. As the virus spread, healthcare supply chains experienced shortages of intensive care capacity, critical medical equipment, vaccines and personal protective equipment for healthcare workers. Demand in food and grocery supply chains rocketed as panic buying emptied supermarket shelves of toilet paper, pasta, flour, infant formula and diapers. Whilst news media covered stories of altruism and heroism of care workers, stories of shameful behaviour emerged; price gouging (OECD, 2020a), corrupt public contracts and profiteering in hasty arrangements for critical supplies (OECD, 2020b), along with lack of PPE in care homes (Iacobucci, 2020) where so many of the most vulnerable died, are all sad indictments. Governments of seemingly respectable countries are alleged to have committed piracy to sequester medical supplies being legally exported (Financial Times, 2020; Bloomberg, 2020). Whilst many clinical research scientists quickly tried to collaborate internationally, focus on supply of critical medical resources and food rapidly became a national, state or local issue (Waldman \& Javidan, 2020).

Most governments responded quickly to the crisis in their country, establishing emergency task forces and enacting pre-prepared pandemic plans and stockpiles. The US and UK were ranked 1 and 2 for preparedness for a pandemic in the Global Health Security (GHS) Index (2019) study by John Hopkins University, Economist Intelligence Unit (EIU) and Nuclear Health Initiative, but the report cautioned that "collectively international preparedness is weak"; however, even prepared countries failed to implement their plans effectively and comprehensively. Within weeks the emergent global shortages and fights for limited supplies internationally were dealt with by government leaders coping with closed borders and lockdowns. In April 2020 the UN passed a second resolution urging international cooperation 
to ensure global access to medicines, vaccines and medical equipment, stating the COVID-19 crisis "brings home the depth of our interconnectedness" (UN, 2020).

How far has the field of supply chain management progressed on research and practice of interconnected phenomena? Connectedness has been at our core since Oliver and Webber (1982) created the brand 'supply chain management' to represent what we would now term the 'internal supply chain', conceptualising the flow of materials from the inbound side of a manufacturer, through transformational stages of production, to the outbound side. But, beyond connectedness, to what extent is our field contributing to the current debates on the types and scale of interconnectedness emerging globally? There have been glimpses of interest in interconnectedness relating to supply chain resilience; in examining interconnectedness in a less developed country context, Tukamuhabwa et al (2017) assert that most interest in supply chain resilience has focused on large, catastrophic, single event disruptions, rather than chronic manifestations of multiple, non-linear, factors connected in an emergent way (echoing Harland et al, 2003, and Juttner and Maklan, 2011). Mostly, however, supply chain management has paid attention to more discrete units of analysis focused on the focal firm (Carter et al, 2015).

This crisis has highlighted supply chain management issues at systems levels beyond the firm and its connected supply chains, emphasising the need for tackling interconnectedness across supply chains, sectors, governments and civil society. The wave of COVID-19 special issues in academic journals and surge of COVID related SCM studies have provided some initial, though limited, consideration of more dynamic, open systems such as 'intertwined supply networks (Ivanov and Dolgui, 2020) and application of existing concepts, such as 'open innovation' (Chesbrough, 2020) to examine this contemporary interconnected crisis. However, tweaking and stretching existing resilience and agility concepts and techniques for 
connected supply chains to respond to COVID-19 is not sufficient. The global supply crises being faced require a more holistic approach from our SCM community to identify and tackle interconnected research problems in a more open way.

Interconnectedness is not a new idea. Lorenz's meteorological illustration of a butterfly flapping its wings in the Amazon rain forest of Brazil being deterministically linked to a tornado in Texas, spawned deterministic chaos theory in the 1960s (Lorenz, 1969, 1995). Six degrees of separation, first attributed to the Hungarian writer Karinthy (1929), proposing that everyone can be connected via 6 social network connections, is not only embedded in popular culture, but is explored through psychology's 'small world' problem' and social networks research. This essay proposes that supply chain management research and practice is already making substantial contributions to understand and deal with connected elements of this global crisis, but we just haven't yet integrated those contributions sufficiently to provide an interconnected perspective. This interconnected perspective is not simply about joining together existing bodies of SCM knowledge, although this in itself is an important task; it is also about focusing attention on the whole, researching and developing holistic, more interconnected approaches to how we treat interconnected phenomena.

An analogy of a tapestry is used here to illustrate and elaborate. Famous tapestries typically contain different religious, war or hunting scenes, the overall tapestry illustrating a story, depicting the entirety of a historical event or revealing the chronology of a historical period. Tapestries are woven by artisans interlacing discontinuous weft threads back and forth across warp threads, working on a particular scene at a time. The thread running through this essay is that the developing field of supply chain management research and practice has groups working on individual tapestry scenes of aspects of how to deal with a global crisis; journal special issues dedicated to COVID-19 examine the crisis from particular perspectives. Each individual scene is important, but this global crisis provides us with a unique opportunity to 
unite our field to produce a tapestry that tells a complete story, rather than a set of separate scenes. Supply chain management has, to date, been more focused on 'connectedness' of forprofit firms with their supply chains, rather than 'interconnectedness' across supply chains and with other not-for-profit actors impacting chains, and stakeholders such as civil society organisations and governments involved in more 'matrixed government' (OECD, 2020c).

Seemingly disconnected questions are posed here to explore themes our field has capability and expertise in that could have greater impact on global crises, if they are joined to form a more interconnected SCM research and practice capability. The questions posed are inspired by conversations with senior public procurement practitioners during the early stages of COVID-19 as part of a research project investigating extraordinary action required to tackle global crises (paper in review) ${ }^{1}$ and with co-organisers and participants of an online forum titled Action Agenda for Post COVID-19 Supply Chains ${ }^{2}$. The questions are devices to illustrate the chronology of how thinking developed, and the discrete strands of SCM knowledge they relate to. These strands are discontinuous wefts, woven together here to conceptualise an interconnected, holistic, systems thinking inspired tapestry of SCM. This perspective is then used to imagine a glimpse of a more coordinated, interconnected, resilient supply chain management approach to global crises generally.

\section{Q1. Early in the COVID-19 crisis, why did no one seem to know the capacity, concentration, capability and membership of supply markets for critical healthcare supplies?}

\footnotetext{
${ }^{1}$ Inspiration from academic colleagues in the International Research Study of Public Procurement is acknowledged: Jan Telgen, Andrea Patrucco, Petra Ferk, Louise Knight, Jane Lynch, Tunde Tatrai, and senior international public procurement practitioners, notably Rick Grimm, Tara Hartley and Richard Lennartz ${ }^{2}$ Inspiration from co-organisers Lisa Ellram, Barbara Flynn, Gyongyi Kovacs, Joe Sarkis and Wendy Tate and participants, notably Gene Schneller, of an online forum available at: https://www.youtube.com/watch?v=Jgoe6iCYLF4\&t=5s
} 
We learnt from the 1918 Spanish Flu pandemic and 2002-2003 SARS outbreak some practical lessons on the importance of social distancing measures, wearing of masks, hand washing, communication and international cooperation (Goudarzi, 2020). Given the predictions of the possibility of a global pandemic and efforts made by governments on preparedness in terms of stock piles and emergency plans, why have many developed countries been woefully unprepared (Timmis and Brussow, 2020), scrambling to evaluate the available national and global capacity of supply markets for critical supplies, almost from a standing start? Reaching the limits of global supply market capacity for these essential supplies rapidly became a profound problem in the COVID-19 crisis, but also the limits of knowledge of these supply markets quickly constrained decision-making. The UN's Health Emergencies Preparedness and Response team responded in April 2020 (WHO, 2020) with a proposed coordinated approach - a 'control tower' - to unite action internationally relating to critical supplies; however, take up in practice has been limited. Of the lessons learnt from Spanish Flu and SARS, local measures to restrict spread of the virus have been implemented, to varying degrees, but less action has been taken on international cooperation and communication regarding critical supplies.

Precisely what is the supply market for ventilators; are they homogeneous as products and do they perform homogeneously when used for patients presenting with a range of respiratory difficulties (Abdulsalam et al 2020)? Prior evidence suggests not (Custer et al, 2011). Have newly developed vaccines been through the same standards of clinical trials assured in some countries? What is the supply market capacity for future vaccine development and, when vaccines become available, will there be sufficient global supply of vials for individual doses and logistics to transport them, particularly from China and India, in the required timescale? International governments made political promises for rapid mass vaccination against 
meningitis in 2015, only to be broken when GlaxoSmithKline released a statement that supply of their vaccine, Bexsero, was constrained - there simply was not sufficient global supply market capacity available at that time. As many nations form bi-lateral arrangements with pharmaceutical partners for COVID-19 vaccine development and national supply, in parallel GAVI COVAX is the UN's WHO platform for supply to richer and low to middle income countries, but it requires advance market commitment (AMC) as well as political, strategic will to eradicate COVID-19 globally. "No one is safe until everyone is" (UN DESA, 2020).

A reality of COVID-19 and other rapid onset crises is that there is insufficient time to research and analyse supply markets from a standing start. Once emergency stockpiles of critical supplies within countries, regions and individual hospitals were exhausted, supply market constraints and their consequences became quickly tangible. Appropriateness of the content and quality of stockpiles, and quality and price of orders placed at speed were questioned. However, should we really have been at a standing start in trying to understand supply markets for critical supplies, their capacities and capabilities? It may be argued that, in a crisis, early understanding of supply market capacities is required, but true preparedness would ensure that this research and supplier development would have occurred before the crisis formed.

The sub-field of supply chain management that deals with supply markets is purchasing and supply management (PSM). At an operational level, PSM practitioners research and connect with supply markets to procure goods and services to satisfy demand i.e. PSM creates connections with suppliers to make goods and services contractually available (Ellram et al 2020). However, immediate demand from the internal customer at the next link in the internal 
supply chain may be disconnected from customer demand at the sales and marketing end of the internal chain. Balancing supply and demand is complicated by the operational transformation process that disconnects these markets at each end of the internal chain.

From a liberalist economic perspective, Hayek's (1945) 'marvel of the market' refers to how little buyers need to know to make choice decisions in markets. Buyers may attempt to research and analyse supply markets they are approaching to gain knowledge on available suppliers, identify who the main actors are, their market shares, and which are local or global, for example. They may assess supplier capability, reliability, reputation and credibility through supplier appraisals using Dun and Bradstreet reports, visiting suppliers, and taking references. Supply market analysis provides understanding of how a market works, which direction it is going in (growing or reducing, investing or declining), how competitive the market is, the capacity and capability of the market, and who the key suppliers are. Deeper research might reveal how suppliers might value the buying organisation as a customer relative to other customers, how the supply market might be developed, the approach to sustainability and ethical issues such as modern slavery and corruption, and pricing variability between suppliers and over time. Supply market research can be categorised into macroeconomic, mesoeconomic and microeconomic (van Weele 1994); for example, the UK Government may analyse macroeconomic global automotive supply markets comparing the UK to other nations, the Society of Motor Manufacturers and Traders might make a mesoeconomic comparison of the importance of the UK automotive supply market relative to other UK industrial sectors, while the London Metropolitan Police Force might analyse the microeconomics of UK automotive manufacturers for procurement of response and nonresponse vehicles. 
As long as there are a number of credible, available suppliers, as Hayek observed, buyers may tolerate lack of market data and knowledge; rather they may content themselves with getting quotations or bids from a number of suppliers, then make a selection based on available vendor ratings of existing suppliers, and comparison of some combination of price, quality, quantity, delivery and service. However, this disguises the fragility of some supply markets where, hidden behind the immediate supplier, is a 'nexus supplier' (Yan et al., 2015) whose supply network position in a number of interconnected supply chains means they may have a profound impact on supply market capacity. Currently there is concern about nexus vaccine glass vial suppliers who are being asked by various competing pharmaceutical manufacturers to reserve capacity just for them (Reuters, 2020).

Comparison between suppliers is easier if there are accepted standards and specifications of goods and services available. In reality, there are only limited sets of circumstances under which buyers have, or seek, detailed knowledge of the supply markets they are procuring from. Examples include buying scarce minerals, buying from highly concentrated supply markets, being a dominant buyer, or needing rapid, local supply, such as in humanitarian aid response to disasters. Visibility and transparency are frequently discussed in supply chain management for existing supply chains (e.g. Srinivasan and Swink, 2018: Swift et al., 2019), less so for analysis of supply markets.

This strand of knowledge that the PSM academic community can bring to dealing with global crises is understanding how to analyse and develop supply markets. As part of emergency planning, supply market capacities of a range of medical and food supplies that might become critical should be examined. Strategic supply market development to increase capacity can be performed at local, national and international levels. However, in practice, 
many decisions in the COVID-19 crisis were made by political leaders exhibiting little understanding of supply markets, their capacity and relative capabilities of suppliers.

Q2. Given that government spending in many developed nations represents $35-50 \%$ of Gross Domestic Product (GDP), why is relatively little SCM research attention paid to public sector supply chain management, and does this matter?

Supply chain management researchers have made limited progress in understanding governments as buyers and supply chain managers; knowledge on public supply chain management lags behind its private sector counterpart (Patrucco et al, 2017). Popular SCM textbooks pay scant attention to public sector supply chain management (e.g. Christopher, 2017; Chopra and Meindl, 2013); this is despite public purchasing power being vast and its potential influence on supply chains and markets, substantial. Depending on the size of the state in different economies, the OECD estimates that government spending impacts on supply chains to the extent of representing 35-50\% of developed countries' GDPs (OECD 2019). This varies as some countries, such as Singapore, has a small public sector, while in China, Russia and some African countries the state still controls much of the economy, including manufacturing, transportation and health services. Not all government spending is made through formal, regulated, public procurement arrangements where suppliers can bid to supply; politicians and powerful suppliers are involved, for example, in countertrade arrangements made between countries and in procuring large construction projects. This makes understanding the total picture of government supply chain management a complex subject to research. 
Whilst public procurement is emerging as an important topic for research (Thai and Piga, 2007), its emphasis differs to for-profit procurement and SCM. Public sector supply chain management tends towards more macro- and meso-economic understanding of supply markets, compared to firm-based SCM that tends to be more focused on the microeconomics of firms' direct connectedness. In part, this difference in emphasis is due to the scale and influence of government spending and its legal and regulatory requirements to treat supply markets equitably as a level playing field (Loader, 2013; Flynn et al, 2013). It is also due to appreciation of how government spending and its influence over supply markets might be leveraged to support broader public policies (Harland et al., 2019) such as stimulating innovation (Georgiou et al, 2014), supporting small businesses (Hawkins et al., 2018), supporting industrial development (Telgen et al, 2012), sustainable supply (Fernandez-Vine, 2013) and improving development of local economies (Vecchiato \& Roveda, 2014).

However, the gap in emphasis between public and private sector SCM is closing as the public sector adopts practices such as 'lean' (Radnor and Walley, 2008) and private sector SCM adopts more 'open' approaches to sourcing such as ‘open innovation' (Chesbrough, 2020), and 'crowd sourcing' (Estelles-Arolas and Gonzalez-Ladron-De-Guevara (2012), which have been shown to be operationally effective. For example, the US Federal Government's use of more open internet platforms outperformed more closed, directly connected EDI technologies in terms of operational supply chain performance (Yao et al, 2009). This echoes AnnaLee Saxenian's findings on Hewlett-Packard's more open approach to its suppliers contributing to the resurgence of the region of Silicon Valley, compared to Digital's more closed approach in the region around Route 128 (Saxenian, 1990) that did not enjoy the same bounce-back at that time. 
Whether understanding of public supply chain management matters or not is answered, in part, by the increased attention to healthcare supply chains in the COVID crisis. Plurality of public and private provision of healthcare services varies substantially across nations, as does structure of complex healthcare sectors. Many countries provide some form of national public health service (e.g. UK and Italy), others have hybrid public and insurance based systems, while some countries (e.g. the US) have highly distributed healthcare systems comprising networks of mainly private, insurance based provision of healthcare, with some form of safety net for uninsured. As we were whipped up in the vortex of the COVID-19 storm, how much understanding did political leaders have about their central, federal, state, regional and local healthcare and procurement systems?

As innovative business leaders quickly volunteered to repurpose their plants to switch to make ventilators, face masks and hand sanitising fluid, how many of those organisations understood how to approach governments to supply them? For actors on both sides of supply relationships at the public-private interface, that interface is quite opaque. In this crisis governments and public procurers lacked capacity and capability to deal with unsolicited donations of PPE; one Canadian city returned $50 \%$ of facemasks donated as it had insufficient capacity to process their receipt, verification, storing and distribution. Communications systems were not present to deal with the surge of offers to supply, so many donors were left unheard by governments, turning instead to complain to the media.

Early involvement and understanding of public procurement and healthcare supply chains in a crisis is insufficient. To be prepared, far greater understanding of these complex, plural supply systems is required. A puppy is not just for Christmas, it needs looking after. 


\section{Q3. Why is supply chain management still largely focused on firm-based decision- making in supply chains with relatively homogeneous characteristics?}

COVID-19 has shone a spotlight on heterogeneity of healthcare and food supply chains in an unprecedented, rapid way. Heterogeneity has become obvious in the lack of international standards and specifications for products and their use in alternative approaches to care provision. Personal Protective Equipment (PPE) and ventilators have been adapted locally to suit different contexts. Perceived variability in standards of clinical trials of potential vaccines is calling their efficacy and safety into question. Relative to manufacturing of cars, computers, fashion and consumer durables, as examples, healthcare is, in the main, a high variety sector. Alternative approaches, treatment pathways and clinical preferences give rise to enormous variety in demand for medical supplies making standardisation and variety reduction challenging. This inherent heterogeneity of healthcare, public health and supply of social care services ripples out across wider supply chains leading to heterogeneity of impact internationally.

This ripple effect of heterogeneity is also evident in food supply chains. In developed countries as demand from restaurants, fast-food outlets and outdoor markets reduced rapidly in COVID-19, it surged in supply chains to supermarkets providing online ordering and home delivery (OECD, 2020c). Whilst shocks and changes are evident across most supply chains, healthcare and food have come more into focus as the basics needed to survive in this situation. The traditional focus of SCM research on more homogeneous, standardised, routinised and systematised supply chains has to expand to learn about structures, processes and capacities in more heterogeneous chains such as healthcare and food. 
Within these heterogeneous contexts, there is heterogeneity of governance mechanisms. Healthcare service provision often occurs through complex networks of collaborating organisations; for example, mental health services may be provided by networks of charities, clinicians, social care workers, engaged patients and carers operating across many organisation boundaries. In healthcare, stakeholder engagement is important; patient voices being heard in decisions on treatment pathways, and health insurers and group purchasing organisations influencing choice are examples of the many network decision-making behaviours impacting healthcare supply chains. Various public and private sector provision arrangements for healthcare exist internationally, with many governments playing central roles in governance and decision-making. Food supply chain governance is also heterogeneous; as one third of the total 4 billion tons of food produced every year globally is wasted (FAO 2011), innovative, collaborative forms of supply chains have been developed to recycle and redistribute food through food banks and other forms of food redistribution, to economically and socially deprived segments of populations. Unpredictability of supply of crops and times of harvest make upstream parts of food supply chains challenging to manage; restrictions of movement of migrant workers common to agriculture are threatening harvesting during the pandemic. Cooperatives in food production are more common forms of governance than in high volume, lower variety manufacturing settings.

Since the original behavioural theory of the firm (Cyert and March, 1963), firm-based decision making still dominates business management thinking and research (Argote and Greve, 2007). Whilst firm-based decision making is the prevailing focus of supply chain management, the extent of control in the supply chain by individual firms is more recently being questioned. Along with language (Ellis and Larsen-Freeman, 2009), technology invention (Fleming and Sorenson, 2001), healthcare (Rouse, 2008), nursing (Chaffee and 
McNeill, 2007), and leadership (Uhl-Bien and Marion, 2009), supply networks (Choi et al 2001) and the supply chain (Carter et al, 2015) have been conceptualised as complex adaptive systems, or CAS. Originating in organismic biology, CAS are self-organising, dynamic systems comprised of hierarchies of interacting, connected sub-systems where behaviour and structure emerge. Whilst hierarchies exist within CAS, there are no inherent hierarchies of command and control. Firms, or agents, battle with the tensions of emergence and control; with limited visibility, they attempt to control portions of supply chains according to their strategic intentions and what is practical. But even this more nuanced view of supply chain management, through the CAS lens, is still focused on individual, powerful firms trying to deal with emergence to capture value in their supply chain.

SCM approaches to sustainability and circular supply chains have made substantial contributions to understanding how individual firms can collaborate more with members of their supply chain to reduce waste (Carter and Rogers 2008). Interdependence in supply chains can give rise to cumulative, systemic change from individual firms' incremental actions (Dooley, 2017). However, to date, the focus has still largely been on firm-based decisions; sustainable supply chain management has been defined as "the strategic, transparent integration and achievement of an organization's social, environmental, and economic goals in the systemic coordination of key interorganizational business processes for improving the long-term economic performance of the individual company and its supply chains"(Carter and Rogers 2008).

Whilst SCM has been characterised as a multi-level hierarchy of interacting sub-systems relating to the internal supply chain, the dyadic buyer-supplier relationship, the supply chain and the supply network (Harland, 1996), this characterisation has still been from the 
perspective of the focal firm. However, as it becomes more accepted that networks compete with networks (Thorelli, 1986) and supply networks with other supply networks (Christopher 2017), how might SCM more fully embrace network-based decision making? Much of the intellectual development on network governance has been made, to date, by organisation studies and leadership researchers, notably Keith Provan (Provan et al, 2007; Provan and Lemaire, 2012); mostly these are studies of healthcare supply networks. Network decisionmaking, as opposed to firm-based decision making is more shared, distributed, collective, relational, dynamic, emergent and adaptive (Popp et al., 2013) with leaders characterised more as 'host' than 'hero' (Keast et al., 2004, Weber and Khademian, 2008). Wicked problems such as global pandemics, poverty and climate change cannot be solved by single agencies, organizations or governments (Huxham and Vangen, 2005, Hoberecht et al., 2011). Complex problems facing societies and economies provide a "moral imperative" to collaborate across organizations and sectors (Popp et al., 2013). Governance of collaborative networks can be through shared governance, lead organisation or an independent network administration organisation (Provan and Kenis, 2008), or hybrids of these (Provan and Lemaire 2012).

The third strand of SCM contribution to be picked up here, therefore, is conceptualising SCM using network, systems and complex adaptive system thinking.

\section{Q4. Is it feasible and / or desirable to form a global supply chain management response to a global crisis?}

Firms will continue to make risk and resilience decisions to ensure continued working and minimise disruption to their supply chains during a crisis; for example, Taiwan Semiconductor Manufacturing and Mazda are creating production plants closer to the US (BCG, 2020). Provision of safe working environments will enable employees to resume work. Larger firms may lobby, but on their own they will be reacting to circumstances and 
decisions made by their government, other governments and international organisations influencing international action. Firm-based SCM research and practice has, therefore, limited scope to contribute to forming a global SCM response; however, firms' aggregate actions will form the backbone of economic recovery. Industry groups and associations can play a positive role in supporting and sharing practices across firm members, improving collective capacity for action (Watkins et al, 2015).

Humanitarian supply chain researchers and practitioners understand particularly the management of healthcare, water, food and shelter supply chains in crisis response situations; their research is largely with governments, NGOs, charities, and United Nations organisations so, like public procurement, has been somewhat on the fringes of mainstream, for-profit SCM. Responses to humanitarian disasters involve coordination across emerging, dynamically changing networks of organisations, governments and individual volunteers. These humanitarian networks are challenging to coordinate (Seybolt, 2009) but there is a developing base of knowledge on how to do this (Quarshie and Leusthner, 2020). Based on the US Federal Emergency Management Agency (FEMA) approach, the widely accepted four phases of crisis management are mitigation, preparedness, response and recovery (Donahue and Joyce, 2001). Mitigation and preparedness improve resilience and capacity to ensure effective recovery (Ponomarov and Holcomb 2009) and reduce cost and time of recovery (Jahre et al 2007). Strategic procurement and location of funds (McGuire and Schneck 2010) and supplies can be anticipated as part of preparedness (Torabi et al. 2018). UNOCHA is the United Nations Office for Coordination of Humanitarian Affairs and already has a structure of country-based pools of finance for local deployment. Prediction, mitigation and preparedness should feature more in any further waves of COVID-19 and other global crises, 
but the severity and spread of the current pandemic is still finding some countries unprepared for further waves (Djalante et al. 2020).

Humanitarian SCM also understands donations management. This COVID-19 crisis saw public procurement and governments unprepared for unsolicited donations (e.g. face masks, handsanitising gel) and how to manage them, yet donations management is vital (van Wassenhove, 2006). From large-scale philanthropic foundations' donations to individuals making face masks for care workers, coordinators of complex humanitarian aid supply networks understand the importance of establishing communications channels, processes and logistics for dealing with cash and in-kind donations. Humanitarian SCM research and practice, therefore, has the potential to make a substantial impact on global crises, particularly those bringing healthcare and food supply chains into focus.

Public procurement researchers and practitioners have been analysing and engaging with supply markets and government policy makers to mobilise spending to secure critical supplies during COVID-19 (Harland et al, paper in review). Rapid contracts for temporary intensive care facilities have been placed and progressed. In public procurement, international collaborations have formed to respond to the crisis. Under the EU Joint Procurement Agreement, the EU procured PPE and medical devices for EU members through DG SANTE which is the directorate responsible for the EU Commission's policies on health and food security and monitoring implementation of related laws. Public procurement SCM research and practice has, and will continue to have, substantial involvement in national and international responses to this crisis.

In terms of feasibility, therefore, there is SCM knowledge and capability to act globally and form a global SCM response, if humanitarian SCM and public procurement research and knowledge is integrated, but this would require a more holistic conception of SCM. To probe 
desirability, the next section glimpses at what a more interconnected approach to supply chain management might offer.

\section{Towards a more interconnected supply chain management tapestry}

Humanitarian supply chain management and public procurement sub-fields of SCM operate at multiple systems levels, conceiving supply chain management as an interconnected endeavour. Purchasing and supply management and firm-based SCM have focused more on firms' decision-making; their empirical research on dyadic relationships, supply chains and supply networks has largely been from the perspective of the focal firm. Whilst examination of supply markets should be the domain of PSM researchers, in practice they have paid less attention to markets than to direct supply relationships (Zsidisin et al, 2019).

Figure 1 is an attempt to convey the foci of these sub-fields of SCM and their recent journal special issues as somewhat separate groups, weaving their own tapestry scenes from their own discontinuous wefts. Central to the figure is a more interconnected conception of SCM, typified by this special issue of JSCM, that provides the structural warp threads for the whole interconnected tapestry.

$<$ Please insert Figure 1 about here $>$

Table 1 provides examples of how different SCM perspectives act as lenses on different systems levels. Collectively they form the warp and weft threads of the interconnected SCM tapestry.

<Please insert Table 1 about here>

In practice, matrixed government, inter-government procurement collaborations, NGOs and United Nations organisations conceive of interconnected solutions to crises and for ongoing development. Firm-based SCM practices and individual firms' local and global actions to improve resilience, agility and sustainability in their connected supply chains are crucial to 
respond to global crises and for long-term economic development. Industry groups represent an important systems level in practice for aggregation across individual firms in sectors, although from an SCM academic perspective, industry sectors are usually the context for empirical research, rather than the unit of analysis.

A global supply chain management response to global crises would integrate supply chain thinking and action at different systems levels. A network administration organisation form of governance is the most likely to be effective to deliver global stewardship of such an interconnected endeavour. On Mar 26 2020, the G20 held a virtual summit and, within that, pledged to resolve disruptions to global supply chains as part of a developing G20 action plan to respond to the COVID-19 crisis. However, it is the UN that is leading the SCM global potential solutions for vaccines and critical supplies.

At national government level, countries have their own disaster / emergency management arrangements. Preparedness decisions can be taken regarding central/ national action and which decisions can be devolved to state/ regional governments. For example, US Senate Legislation July 182020 decided to build up stockpiles of critical supplies within states, allocate funds for onshore production of antibody and antigen testing materials and future vaccines, build national strategic stockpiles and design a 'whole of government' strategy. China, Singapore and Wales centralised all procurement for COVID-19. However, most governments' emergency plans were unprepared for closed international borders.

\section{Conclusions and SCM research opportunities}

Traditional firm-based SCM has concentrated more on connectedness, predominantly of resources. Purchasing and supply-oriented SCM has focused on connectedness of relationships and contracts and less on interconnected issues affecting supply markets. Humanitarian-oriented SCM has focused on interconnectedness of networks of organisations 
coming together in disasters. Public procurement-oriented SCM has focused on interconnectedness of public services and supply markets. The COVID-19 global pandemic involved and affected all these strands of supply chain management and therefore, effectively connected them in an emergent, CAS way. but bigger systems levels thinking about SCM needs to consider interconnectedness across many connected networks and at multiple systems levels. Global crises demand a more holistic approach to SCM, weaving together currently disconnected wefts of SCM knowledge into a multi-scene tapestry. More research is required on interconnected phenomena. Empirically driven theoretical SCM research is required to move beyond thinking about supply chains as complex adaptive systems dealing with emergence from a firm-based perspective, towards network and system (networks of networks) level understanding and action. Focal firm-based concepts and theories, beyond the behavioural theory of the firm, should be supplemented with greater development and application of network theory and systems thinking. More broadly, network and systemsbased theories and multi-level approaches should be embraced and developed by SCM researchers to tackle supply chain aspects of other 'wicked' problems such as sustainability, poverty, water and food availability, and dislocated populations.

We should also conceive of a future that is better than the past. In SCM transiliency has been proposed as how supply chains radically restore processes and change to a better state than before COVID-19 (Craighead et al, 2020). This echoes the UN program of 'build back better' in the United Nations Sendai Framework for Disaster Risk Reduction (UNISDR, 2015). The UN Comprehensive Response to COVID-19 issued June 2020 by the UN Secretary General aims to coordinate the UN system to save lives, protect societies and recover better (build back better). This interconnected, global future should be one "that leaves no one behind" (UN Secretary General, 2020). 
Practically, our SCM community should build on this special issue, using it to provoke debate and action, to bring together the SCM academic sub-fields and practice leaders to form a shared research agenda for a more interconnected SCM future.

\section{References}

Abdulsalam, Y., Alhuwail, D., \& Schneller, E. S. (2020). Adopting Identification Standards in the Medical Device Supply Chain. International Journal of Information Systems and Supply Chain Management (IJISSCM), 13(1), 1-14.

Argote, L., \& Greve, H. R. (2007). A behavioral theory of the firm-40 years and counting: Introduction and impact. Organization science, 18(3), 337-349.

BCG (2020) Resilience in global supply chains Boston Consulting Group Publications https://www.bcg.com/publications/2020/resilience-in-global-supply-chains

Bloomberg (2020)

https://www.bloomberg.com/news/articles/2020-03-09/germany-faces-backlash-from-neighbors-overmask-export-ban

Carter, C. R., Rogers, D. S., \& Choi, T. Y. (2015). Toward the theory of the supply chain. Journal of Supply Chain Management, 51(2), 89-97.

Carter, C. R., \& Rogers, D. S. (2008). A framework of sustainable supply chain management: moving toward new theory. International journal of physical distribution \& logistics management.

Chaffee, M. W., \& McNeill, M. M. (2007). A model of nursing as a complex adaptive system. Nursing outlook, 55(5), 232-241.

Chesbrough, H. (2020). To recover faster from Covid-19, open up: Managerial implications from an open innovation perspective. Industrial Marketing Management.

Choi, T. Y., Dooley, K. J., \& Rungtusanatham, M. (2001). Supply networks and complex adaptive systems: control versus emergence. Journal of operations management, 19(3), 351366.

Christopher, M. I. (2017). Logistics \& supply chain management, $4^{\text {th }}$ Edition, Pearson Education

Christopher, M. (2011). Logistics \& supply chain management. Pearson education limited.

Chopra, S. and Meindl, P. (2013). Supply Chain Management: Strategy, Planning, And Operation, 5/e. Pearson India.

Craighead, C. W., Ketchen Jr, D. J., \& Darby, J. L. (2020). Pandemics and Supply Chain Management Research: Toward a Theoretical Toolbox. Decision Sciences. 
Custer, Jason W. MD; Watson, Christopher M. MD, MPH; Dwyer, Joe RRT; Kaczka, David W. MD, PhD; Simon, Brett A. MD, PhD; Easley, R. Blaine MD (2011), Critical evaluation of emergency stockpile ventilators in an in vitro model of pediatric lung injury, Pediatric Critical Care Medicine: 12 (6), 357-361, doi: 10.1097/PCC.0b013e31820ab891

Cyert, R. M., \& March, J. G. (1963). A behavioral theory of the firm. Englewood Cliffs, NJ, 2(4), 169-187.

Djalante, R., Shaw, R., \& DeWit, A. (2020). Building resilience against biological hazards and pandemics: COVID-19 and its implications for the Sendai Framework. Progress in Disaster Science, 100080.

Donahue, A. K., \& Joyce, P. G. (2001). A framework for analyzing emergency management with an application to federal budgeting. Public Administration Review, 61(6), 728-740.

Dooley, K. (2017). Value chain systemicity: Promoting organizational creativity and environmental sustainability in low velocity industries. Journal of cleaner production, 140, 1903-1913.

Ellis, N. C., \& Larsen-Freeman, D. (2009). Language as a complex adaptive system (Vol. 11). John Wiley \& Sons.

Ellram, L. M., Harland, C. M., van Weele, A., Essig, M., Johnsen, T., Nassimbeni, G.,Pagell, M., van Raaij, E., Rozemeijer, F., Tate, W.,and Wynstra, F. (2020). Purchasing and supply management's identity: Crisis? What crisis?. Journal of Purchasing and Supply Management, 26(1), 100583.

Estellés-Arolas, E., \& González-Ladrón-De-Guevara, F. (2012). Towards an integrated crowdsourcing definition. Journal of Information science, 38(2), 189-200.

FAO. (2011). Global Food Losses and Food Waste: Extent, Causes and Prevention. In Food Loss and Food Waste: Causes and Solutions. https://doi.org/10.4337/9781788975391

Fernández-Viñé, M. B., Gómez-Navarro, T., \& Capuz-Rizo, S. F. (2013). Assessment of the public administration tools for the improvement of the eco-efficiency of Small and Medium Sized Enterprises. Journal of Cleaner Production, 47, 265-273.

Financial Times (2020) https://www.ft.com/content/03e45e35-ab09-4892-899d$\underline{\mathrm{a} 86 \mathrm{db} 08 \mathrm{a} 935 \mathrm{c}}$

Fleming, L., \& Sorenson, O. (2001). Technology as a complex adaptive system: evidence from patent data. Research policy, 30(7), 1019-1039

Flynn, A., Davis, P., McKevitt, D., \& McEvoy, E. (2013). Mapping public procurement in Ireland. Public Procurement Law Review, 2013(2), 74-95..

Georghiou, L., Edler, J., Uyarra, E., \& Yeow, J. (2014). Policy instruments for public procurement of innovation: Choice, design and assessment. Technological Forecasting and Social Change, 86, 1-12.

Global Health Security Index (2019) https://www.ghsindex.org/wpcontent/uploads/2020/04/2019-Global-Health-Security-Index.pdf 
Goudarzi, S (2020) Lessons from past outbreaks could help fight the coronavirus pandemic, https://www.scientificamerican.com/article/lessons-from-past-outbreaks-could-help-fight-thecoronavirus-pandemic1/

Harland, C. M. (1996). Supply chain management: relationships, chains and networks. British Journal of management, 7, S63-S80.

Harland, C., Brenchley, R., \& Walker, H. (2003). Risk in supply networks. Journal of Purchasing and Supply management, 9(2), 51-62.

Harland, C., Telgen, J., Callender, G., Grimm, R., \& Patrucco, A. (2019) Implementing government policy in supply chains: an international coproduction study of public procurement. Journal of Supply Chain Management, 55, 2, 6-25

Harland, C., Telgen, J., Patrucco, A., Ferk, P., Knight, L., Lynch, J., Peters, E., Tatrai, T., (paper in review), Procurement in a global crisis: a call for extraordinary action

Hawkins, T., Gravier, M., \& Randall, W. S. (2018). Socio-economic sourcing: benefits of small business set-asides in public procurement. Journal of Public Procurement.

Hayek, F., (1945), The Use of Knowledge in Society, American Economic Review, 35(4), 519-530

Hoberecht, S., Joseph, B., Spencer, J., \& Southern, N. (2011). Inter-organizational networks. OD and Sustainability, 43(4), 23.

Huxham, C. V., \& Vangen, S. S., (2005). Managing to Collaborate-The Theory and Practice of Collaborative Advantage, Routledge

Iacobucci G (2020) Covid-19: Lack of PPE in care homes is risking spread of virus, leaders warn, British Medical Journal News BMJ 2020;368:m1280

Ivanov, D., \& Dolgui, A. (2020). Viability of intertwined supply networks: extending the supply chain resilience angles towards survivability. A position paper motivated by COVID19 outbreak. International Journal of Production Research, 58(10), 2904-2915.

Jahre, M., Persson,G., Kovács, G., \& Spens, K. M. (2007). Humanitarian logistics in disaster relief operations. International Journal of Physical Distribution \& Logistics Management, $37(2), 99-114$.

Jüttner, U., \& Maklan, S. (2011). Supply chain resilience in the global financial crisis: an empirical study. Supply Chain Management: An International Journal, Jun

Karinthy, F. (1929). Láncszemek. Minden másképpen van. Atheneum, Budapest, Hungary.

Keast, R., Mandell, M.P., Brown, K., and Woolcock, G., (2004) Network structures: Working differently and changing expectations. Public Administration Review, 64, 363-371.

Loader, K. (2013). Is public procurement a successful small business support policy? A review of the evidence. Environment and Planning C: Government and Policy, 31(1), 39-55

Lorenz, E. N. (1969). Atmospheric predictability as revealed by naturally occurring analogues. Journal of the Atmospheric sciences, 26(4), 636-646. 
Lorenz, E. N. (1995). The essence of chaos. University of Washington press

McGuire, M., \& Schneck, D. (2010). What if Hurricane Katrina hit in 2020? The need for strategic management of disasters. Public Administration Review, 70, s201-s207.

OECD (2019), Government at a Glance 2019, OECD Publishing,

Paris, https://doi.org/10.1787/8ccf5c38-en

OECD (2020a) Exploitative pricing in the time of COVID-19,

https://www.oecd.org/competition/Exploitative-pricing-in-the-time-of-COVID-19.pdf

OECD (2020b) Public integrity for an effective COVID-19 response and recovery

https://www.oecd.org/coronavirus/policy-responses/public-integrity-for-an-effective-covid19-response-and-recovery-a 5c35d8c/

OECD (2020c) COVID-19 and the food and agriculture sector issues and policy response http://www.oecd.org/coronavirus/policy-responses/covid-19-and-the-food-and-agriculturesector-issues-and-policy-responses-a23f764b/

Oliver, RK, \& Webber, MD (1982). Supply-chain management: Logistics catches up with strategy. Outlook; reprinted in Christopher, MG (1992), Logistics, the strategic issue (pp. 6375).

Patrucco, A. S., Luzzini, D., \& Ronchi, S. (2017). Research perspectives on public procurement: content analysis of 14 years of publications in the Journal of Public Procurement, Journal of Public Procurement, 17(2).

Ponomarov, S. Y., \& Holcomb, M. C. (2009). Understanding the concept of supply chain resilience. The international journal of logistics management, 20(1), 124-143.

Popp, J., MacKean, G., Casebeer, A., Milward, H. B., \& Lindstrom, R. (2013). Interorganizational networks. A critical review of the literature to inform practice. Washington, DC: IBM Center for The Business Development.

Provan, K. G., Fish, A., \& Sydow, J. (2007). Interorganizational networks at the network level: A review of the empirical literature on whole networks. Journal of management, 33(3), 479-516.

Provan, K.G. and Kenis, P (2008) Modes of network governance: Structure, management, and effectiveness. Journal of public administration research and theory, 18, 229-252.

Provan, K. G., \& Lemaire, R. H. (2012). Core concepts and key ideas for understanding public sector organizational networks: Using research to inform scholarship and practice. Public Administration Review, 72(5), 638-648.

Quarshie, A. M., and Leuschner, R. (2020), "Interorganizational Interaction in Disaster Response Networks: A Government Perspective”, Journal of Supply Chain Management.

Radnor, Z., \& Walley, P. (2008). Learning to walk before we try to run: adapting lean for the public sector. Public money and management, 28(1), 13-20.

Reuters (2020) https://www.reuters.com/article/us-health-coronavirus-schott-exclusiveidUSKBN23J0SN 
Rouse, W. B. (2008). Health care as a complex adaptive system: implications for design and management. Bridge-Washington-National Academy of Engineering-, 38(1), 17.

Saxenian, A. (1990). Regional networks and the resurgence of Silicon Valley. California management review, 33(1), 89-112.

Seybolt, T. B. (2009). Harmonizing the humanitarian aid network: Adaptive change in a complex system. International Studies Quarterly, 53(4), 1027-1050.

Srinivasan, R., \& Swink, M. (2018). An investigation of visibility and flexibility as complements to supply chain analytics: An organizational information processing theory perspective. Production and Operations Management, 27(10), 1849-1867.

Swift, C., Guide Jr, V. D. R., \& Muthulingam, S. (2019). Does supply chain visibility affect operating performance? Evidence from conflict minerals disclosures. Journal of Operations Management, 65(5), 406-429.

Telgen, J., Harland, C., \& Knight, L. (2012). Public procurement in perspective. In Public procurement (pp. 44-52). Routledge.

Thai, K. V., \& Piga, G. (2007). Advancing public procurement: Practices, innovation, and knowledge sharing. Boca Raton, FL: PrAcademics Press.

Thorelli, H. B. (1986). Networks: between markets and hierarchies. Strategic management journal, 7(1), 37-51.

Timmis, K., \& Brüssow, H. (2020). The COVID-19 pandemic: some lessons learned about crisis preparedness and management, and the need for international benchmarking to reduce deficits. Environmental Microbiology. 22(6), 1986-1996

Torabi, S. A., Shokr, I., Tofighi, S., \& Heydari, J. (2018). Integrated relief pre-positioning and procurement planning in humanitarian supply chains. Transportation Research Part E: Logistics and Transportation Review, 113, 123-146.

Tukamuhabwa, B., Stevenson, M., \& Busby, J. (2017). Supply chain resilience in a developing country context: a case study on the interconnectedness of threats, strategies and outcomes. Supply Chain Management: An International Journal.

Uhl-Bien, M., \& Marion, R. (2009). Complexity leadership in bureaucratic forms of organizing: A meso model. The Leadership Quarterly, 20 (4), 631-650.

United Nations Office for Disaster Risk Reduction (UNISDR) (2015) Build back better in recovery, rehabilitation and reconstruction. UN Sendai Framework

UN DESA (2020) United Nations Department of Economic and Social Affairs https://www.un.org/development/desa/en/news/sustainable/no-one-is-safe-until-everyoneis.html

UN (2020) 'Global solidarity to fight the coronavirus disease 2019 (COVID-19)', (A/RES/74/270), 2 April, 2020

United Nations Secretary General (2020) United Nations Comprehensive Response to COVID-19, June 2020

van Wassenhove, L. N. (2006). Humanitarian aid logistics: supply chain management in high gear. Journal of the Operational research Society, 57(5), 475-489. 
van Weele, A.J. (1994) Purchasing management: analysis, planning and practice, Chapman and Hall, London

Vecchiato, R., \& Roveda, C. (2014). Foresight for public procurement and regional innovation policy: The case of Lombardy. Research Policy, 43(2), 438-450.

Waldman D.A., Javidan M. (2020) The false dichotomy between globalism and nationalism, Harvard Business Review, https://hbr.org/2020/06/the-false-dichotomy-between-globalismand-nationalism

Watkins, A., Papaioannou, T., Mugwagwa, J., \& Kale, D. (2015). National innovation systems and the intermediary role of industry associations in building institutional capacities for innovation in developing countries: A critical review of the literature. Research Policy, 44(8), 1407-1418.

Weber, E.P. and Khademian, A.M. (2008) Wicked problems, knowledge challenges, and collaborative capacity builders in network settings. Public Administration Review, 68, 334349 .

WHO (2020), COVID-19 Supply Chain System: Requesting and receiving supplies, https://www.who.int/publications/m/item/covid-19-supply-chain-system-requesting-andreceiving-supplies

Yan, T., Choi, T. Y., Kim, Y., \& Yang, Y. (2015). A theory of the nexus supplier: A critical supplier from a network perspective. Journal of Supply Chain Management, 51(1), 52-66.

Yao, Y., Dresner, M., \& Palmer, J. (2009). Private network EDI vs. Internet electronic markets: a direct comparison of fulfillment performance. Management Science, 55(5), 843852.

Zsidisin, G. A., Lamming, R., Harland, C., Wynstra, F., Ancarani, A., Tate, W. L., \& Knight, L. (2019). Reflecting on the past 25 years of the journal of purchasing and supply management: The editors' perspectives. Journal of Purchasing and Supply

Management, 25(4), 100559.

FIGURE 1

An interconnected SCM tapestry 


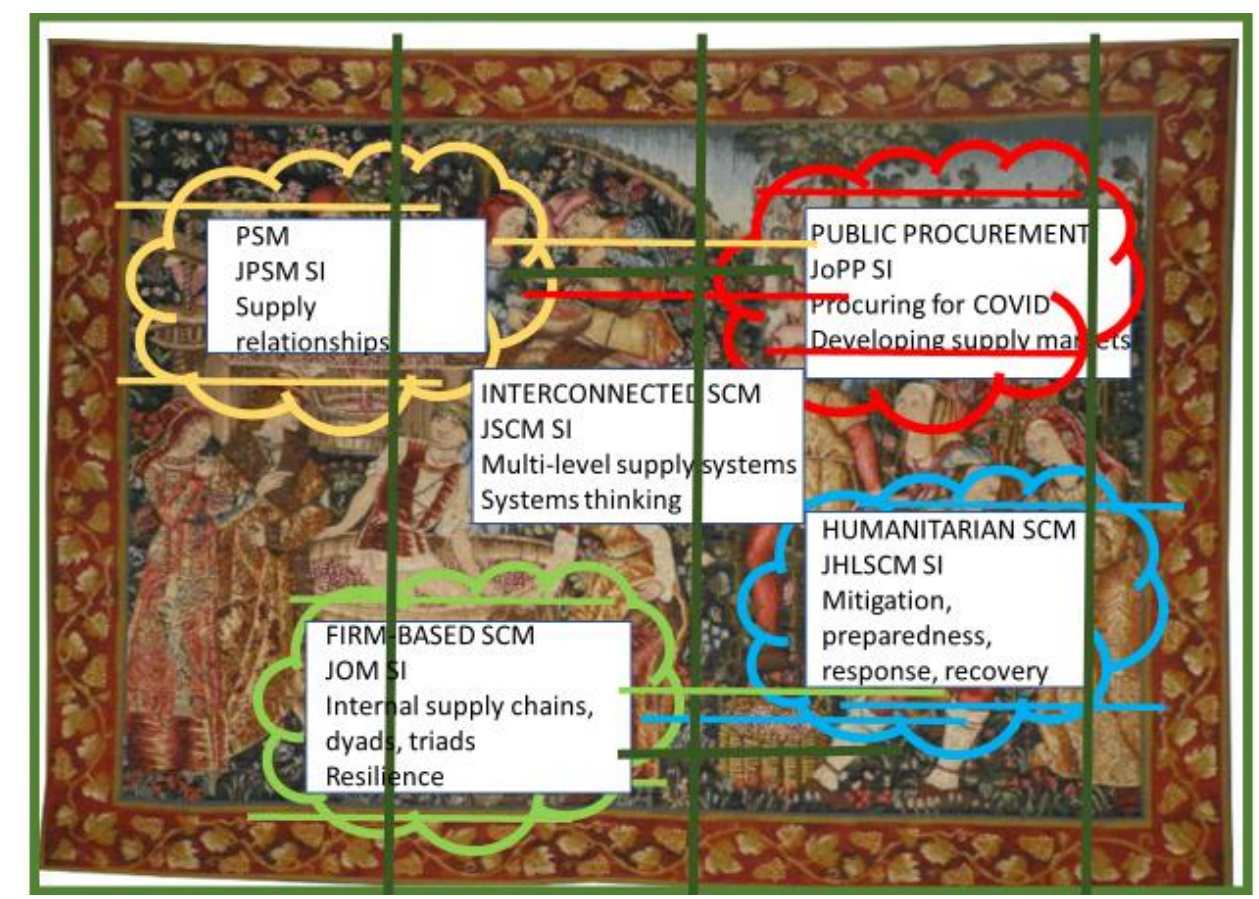

TABLE 1

Systems levels of SCM perspectives

\begin{tabular}{|l|l|l|l|l|l|}
\hline SCM lens & $\begin{array}{l}\text { Firm-based } \\
\text { SCM }\end{array}$ & $\begin{array}{l}\text { Industry } \\
\text { groups }\end{array}$ & $\begin{array}{l}\text { Public } \\
\text { procurement/ } \\
\text { government }\end{array}$ & $\begin{array}{l}\text { Humanitarian } \\
\text { aid SCM }\end{array}$ & $\begin{array}{l}\text { Interconnected } \\
\text { SCM }\end{array}$ \\
\hline $\begin{array}{l}\text { Local/ } \\
\text { organisation/ } \\
\text { state }\end{array}$ & $\begin{array}{l}\text { Local risk and } \\
\text { resilience. } \\
\text { Local supply } \\
\text { market } \\
\text { analysis and } \\
\text { development. } \\
\text { Modifying } \\
\text { work practices } \\
\text { to local } \\
\text { requirements } \\
\text { e.g. local } \\
\text { lockdowns }\end{array}$ & $\begin{array}{l}\text { Local } \\
\text { industry } \\
\text { groups } \\
\text { networking } \\
\text { across local } \\
\text { firms. } \\
\text { Local supply } \\
\text { market } \\
\text { development }\end{array}$ & $\begin{array}{l}\text { Local supply } \\
\text { market } \\
\text { analysis and } \\
\text { development } \\
\text { Local } \\
\text { community } \\
\text { engagement. }\end{array}$ & $\begin{array}{l}\text { Small } \\
\text { business } \\
\text { targeted } \\
\text { agencies help } \\
\text { implement } \\
\text { vaccine } \\
\text { programme } \\
\text { with local } \\
\text { healthcare } \\
\text { providers } \\
\text { Local food / } \\
\text { grocery } \\
\text { distribution to } \\
\text { poorer } \\
\text { communities }\end{array}$ & $\begin{array}{l}\text { Lopport for } \\
\text { networks of key } \\
\text { firms, local } \\
\text { industry groups, } \\
\text { local } \\
\text { government, } \\
\text { public } \\
\text { procurement and } \\
\text { local aid } \\
\text { organisations to } \\
\text { coordinate } \\
\text { critical supplies }\end{array}$ \\
& & $\begin{array}{l}\text { contracting } \\
\text { for local } \\
\text { schools, } \\
\text { hospitals and } \\
\text { care homes }\end{array}$ & $\begin{array}{l}\text { Supply } \\
\text { market } \\
\text { analysis and }\end{array}$ & $\begin{array}{l}\text { Help to } \\
\text { implement } \\
\text { national }\end{array}$ & $\begin{array}{l}\text { National SCM } \\
\text { networks of key } \\
\text { firms, industry }\end{array}$ \\
\hline
\end{tabular}




\begin{tabular}{|c|c|c|c|c|c|}
\hline & \begin{tabular}{|l} 
borders close \\
Repurpose \\
manufacturing \\
to support \\
national needs. \\
Reconcile \\
national \\
demands with \\
global \\
resilience \\
planning \\
Reshoring \\
Support \\
national \\
supplier \\
relationships
\end{tabular} & $\begin{array}{l}\text { industry } \\
\text { groups and } \\
\text { associations } \\
\text { for critical } \\
\text { safety, health } \\
\text { and food } \\
\text { supplies } \\
\text { Lobbying } \\
\text { government } \\
\text { on policy and } \\
\text { regulation }\end{array}$ & $\begin{array}{l}\text { development } \\
\text { for critical } \\
\text { supplies. } \\
\text { Greater } \\
\text { centralised } \\
\text { and } \\
\text { collaborative } \\
\text { public } \\
\text { procurement } \\
\text { - e.g. lead, } \\
\text { piggy-back } \\
\text { procurement } \\
\text { Or outsource } \\
\text { to central } \\
\text { national } \\
\text { agency }\end{array}$ & $\begin{array}{l}\text { vaccine } \\
\text { programme } \\
\text { working with } \\
\text { national health } \\
\text { organisations. } \\
\text { National } \\
\text { donations } \\
\text { campaigns } \\
\text { National } \\
\text { emergency } \\
\text { plans - } \\
\text { mitigate, } \\
\text { prepare, } \\
\text { respond, } \\
\text { recover } \\
\text { National food } \\
\text { distribution } \\
\text { programmes to } \\
\text { poorer } \\
\text { communities }\end{array}$ & $\begin{array}{l}\text { associations, } \\
\text { government, } \\
\text { public } \\
\text { procurement and } \\
\text { aid } \\
\text { organisations to } \\
\text { form and } \\
\text { implement } \\
\text { emergency plans } \\
\text { National stress } \\
\text { testing of supply } \\
\text { chains under } \\
\text { different } \\
\text { potential crisis } \\
\text { scenarios }\end{array}$ \\
\hline International & $\begin{array}{l}\text { Risk } \\
\text { management } \\
\text { and resource } \\
\text { orchestration / } \\
\text { reallocation of } \\
\text { resources } \\
\text { supporting } \\
\text { affected } \\
\text { regions within } \\
\text { the global } \\
\text { supply } \\
\text { network }\end{array}$ & $\begin{array}{l}\text { International } \\
\text { trade } \\
\text { associations } \\
\text { create policy } \\
\text { guidance for } \\
\text { members } \\
\text { International } \\
\text { associations } \\
\text { work with } \\
\text { international } \\
\text { governments } \\
\text { on } \\
\text { procurement }\end{array}$ & $\begin{array}{l}\text { International } \\
\text { government } \\
\text { procurement } \\
\text { e.g EU public } \\
\text { procurement } \\
\text { - DG Sante. } \\
\text { International } \\
\text { government } \\
\text { organisations } \\
\text { e.g. G7 } \\
\text { represent } \\
\text { developed } \\
\text { nations } \\
\text { supply chains } \\
\text { and could } \\
\text { impact on } \\
\text { global } \\
\text { standards/ } \\
\text { specifications }\end{array}$ & $\begin{array}{l}\text { Coordinated } \\
\text { response in } \\
\text { badly affected } \\
\text { regions }\end{array}$ & $\begin{array}{l}\text { International } \\
\text { networks of key } \\
\text { firms, industry } \\
\text { associations, } \\
\text { governments, } \\
\text { international } \\
\text { public } \\
\text { procurement, } \\
\text { and international } \\
\text { aid } \\
\text { organisations. }\end{array}$ \\
\hline Global & $\begin{array}{l}\begin{array}{l}\text { Global risk } \\
\text { and resilience } \\
\text { planning } \\
\text { (transilience). }\end{array} \\
\text { Global firms } \\
\text { central to } \\
\text { crisis liaise } \\
\text { with global } \\
\text { crisis SCM }\end{array}$ & $\begin{array}{l}\text { Global fora } \\
\text { and } \\
\text { associations } \\
\text { represent the } \\
\text { industry in } \\
\text { global crisis } \\
\text { SCM }\end{array}$ & $\begin{array}{l}\text { Global } \\
\text { government } \\
\text { economic } \\
\text { development } \\
\text { organisations } \\
\text { e.g. G20 } \\
\text { financial } \\
\text { support and } \\
\text { lead on } \\
\text { forming and } \\
\text { supporting }\end{array}$ & $\begin{array}{l}\text { UN global } \\
\text { stewardship of } \\
\text { aid e.g. GAVI } \\
\text { COVAX } \\
\text { providing } \\
\text { vaccines to } \\
\text { low- and } \\
\text { middle-income } \\
\text { countries, } \\
\text { WHO health } \\
\text { clusters, }\end{array}$ & $\begin{array}{l}\text { Networked } \\
\text { global } \\
\text { stewardship of } \\
\text { SCM of } \\
\text { vaccines and } \\
\text { other critical } \\
\text { supplies as a } \\
\text { shared } \\
\text { endeavour } \\
\text { across UN and } \\
\text { G20 members }\end{array}$ \\
\hline
\end{tabular}




\begin{tabular}{|l|l|l|l|l|}
\hline & & $\begin{array}{l}\text { global } \\
\text { stewardship }\end{array}$ & $\begin{array}{l}\text { Unicef } \\
\text { vaccines } \\
\text { programme, } \\
\text { UNOCHA } \\
\text { funds } \\
\text { deployment } \\
\text { UN global } \\
\text { procurement } \\
\text { e.g. Unicef, } \\
\text { UNDP IAPSO, } \\
\text { UN IAWGP }\end{array}$ & $\begin{array}{l}\text { Global sourcing } \\
\text { approach with } \\
\text { global pharma }\end{array}$ \\
& & \\
& & \\
& & \\
& & \\
& & \\
& & \\
\end{tabular}

